\title{
Transitions between informal and formal employment: results from a worker survey in Bangladesh
}

Italo A. Gutierrez ${ }^{1 *}$ (D, Krishna B. Kumarr ${ }^{1}$, Minhaj Mahmud ${ }^{2}$, Farzana Munshi ${ }^{3}$ and Shanthi Nataraj ${ }^{1}$

* Correspondence: italo@rand.org ${ }^{1}$ RAND Corporation, 1776 Main Street, Santa Monica, CA 90407, USA

Full list of author information is available at the end of the article

\begin{abstract}
We study transitions between different types of formal and informal employment using retrospective job histories from a new survey in Bangladesh. Workers transitioning between jobs are most likely to remain in the same type of employment, although there is still substantial churn across employment types. Private wage employees have higher probability of transitioning to a new job, and changes in earnings and benefits suggest evidence of upward mobility. Nevertheless, there is also non-trivial risk of downward mobility, especially for those transitioning into casual employment, which has the lowest level of earnings and benefits and the highest levels of exposure to workplace hazards and violence. Overall, the informal sector appears to include subpopulations consistent with both the traditional view that it is a segmented portion of the labor market with few prospects of upward mobility, and with the alternative view that it is a dynamic, entrepreneurial alternative to wage employment.
\end{abstract}

JEL Classification: J320, J460, J620

Keywords: Informal labor, Self-employment, Casual workers, Job transitions, Working conditions, Job benefits

\section{Introduction}

Throughout the developing world, a significant share of workers is informally employed (ILO 2014). The traditional view of informality is that labor markets are segmented in formal and informal sectors, with workers who cannot find jobs in the formal sector turning to informal work out of necessity. In this view, the informal sector is seen as stagnant and less productive than the formal sector, serving as a pool of surplus labor, or providing subsistence income for those unable to obtain formal employment (e.g., Chandra and Khan 1993; Fields 1975; Harris and Todaro 1970). In this paradigm, the informal sector is unlikely to contribute to growth and is expected to disappear in the long run as the economy develops.

However, other researchers have argued for an alternative view of informality, in which workers can choose and transition between the formal and informal sectors. Individuals may decide to become self-employed to become their own bosses, to take risks, or because running a household business provides greater life satisfaction than

(c) The Author(s). 2019 Open Access This article is distributed under the terms of the Creative Commons Attribution 4.0 International License (http://creativecommons.org/licenses/by/4.0/), which permits unrestricted use, distribution, and reproduction in any medium, provided you give appropriate credit to the original author(s) and the source, provide a link to the Creative Commons license, and indicate if changes were made. 
working in an enterprise (Fajnzylber et al. 2006). Other individuals may choose to work in enterprises that do not offer job benefits in exchange for higher cash earnings (Maloney 1999).

The literature contains a multitude of definitions for informality, ranging from employees in enterprises who do not have access to specific job benefits, to those who work in enterprises with few employees or not registered with government authorities, to all workers who run or work in household-based businesses. Rather than viewing formality and informality in a strictly binary sense, the degree of formality may be more usefully viewed on a continuum. At one end of the continuum are jobs that offer no benefits and potentially hazardous or otherwise undesirable working conditions. At the other end of the continuum are jobs that are highly formalized, with long-term contracts, paid leave, and a pension. Workers who move between jobs might gain or lose certain benefits.

In this paper, we provide evidence on whether, and how, workers transition between different types of employment in Bangladesh. Bangladesh has experienced strong GDP growth over the last two decades (ranging from around 4-7\% per year); per capita income has also grown between 2 and 6\% per year (World Bank 2018). Nonetheless, the informal sector continues to account for the vast majority of employment (Bangladesh Bureau of Statistics 2013).

We use information on job histories collected from approximately 2000 workers in the metropolitan areas of Dhaka and Chittagong. In our survey, we asked workers about the benefits they receive in their current jobs and up to two previous jobs they held over the past 15 years. These retrospective data allow us to examine whether workers appear to be segmented into different types of employment, or whether they transition between jobs with different degrees of formality.

Our study contributes to the literature on informal work in several ways. First, nearly all of the empirical evidence on employment transitions in developing countries comes from middle-income countries (e.g., Arias et al. 2013; Bosch and Maloney 2010; Fajnzylber et al. 2006; Goldberg and Pavcnik 2003; Maloney 1999; Nataraj 2011; Paz 2014) or from cross-country studies (e.g., Djankov and Ramalho 2009; LaPorta and Shleifer 2008; Loayza et al. 2005). Very little is known about the nature of informality in low-income countries (LICs), or in South Asia more broadly. Since conditions that affect the nature of informal work and the decisions that employers make about how to operate-such as infrastructure, institutions, degree of enforcement, and the functioning of credit markets-can be fundamentally different in LICs than in more developed countries, it is critical to empirically examine how informal labor markets function in LICs. Second, our retrospective survey allows us to capture transitions over a period of up to 15 years, which is substantially longer than is often captured in studies of employment transitions. ${ }^{1}$ Third, our survey asks respondents about a rich variety of job benefits-including contracts, paid sick leave, paid casual leave (vacation), termination notice, and retirement benefits-for current and previous employment. Thus, we are able to examine whether workers are able to move up or down a "formality ladder" using a more continuous measure of formality. ${ }^{2}$ Finally, our survey included information about the reasons for choosing self-employment, about several working conditions (hazards, hygiene, and advancement opportunities, among others), and about overall work satisfaction. These complementary questions are helpful in evaluating whether 
individuals perceive jobs with fewer benefits as providing alternative opportunities, or as simply being the employment of last resort, and in comparing these jobs with more formal jobs regarding basic working conditions.

\section{Survey methods}

\subsection{Sampling design}

We used a two-stage sampling design to select workers to interview in four zilas (districts): Dhaka, Gazipur, and Narayanganj zilas in the Dhaka metropolitan area and Chittagong zila in the Chittagong metropolitan area. As we were unable to obtain a recent sampling frame for households, we began with a list of the number of households in each of 1971 mouzas (the lowest administrative level for which such data were available) in the four targeted zilas. We used the mouza as our primary sampling unit (PSU). We selected 80 mouzas with probability proportional to size (PPS) where size was the number of households. ${ }^{3}$

Within each mouza, we selected 30 households for first-stage sampling, using a random walk method, as follows. Three enumerators, plus a supervisor, would arrive at the selected mouza. The supervisor first reviewed the general layout of households in the mouza, and then directed each enumerator to start at a different point, typically along the outside border of the mouza. The enumerator was instructed to visit every 10th household. ${ }^{4}$ At each selected household, we used a screener to collect basic information about all household members, including age, gender, employment status, and type of employment. Figure 1 shows the locations of all households that responded to the screener.

The objective of using the screener was to identify currently working adults to be selected for our survey. We collected a roster of approximately 3800 currently working

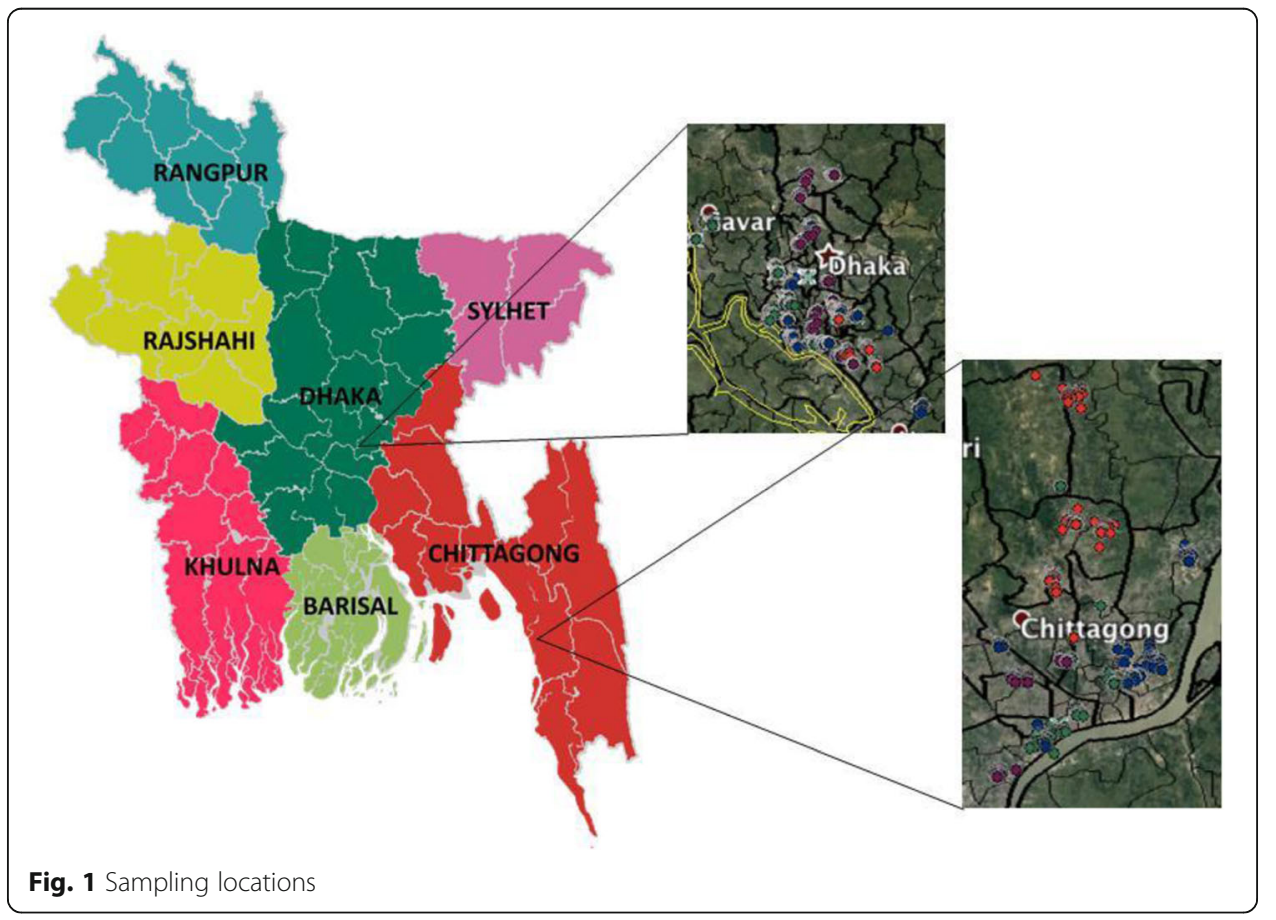


adults. Since one of the key aims of the study was to understand transitions between employment types, we stratified the roster by the employment types shown in Table 1. We also stratified by gender to make sure we included enough women in the study (as women are underrepresented in the labor force). Our target sample size was 2000 currently working adults. Within the smaller gender-employment-type strata, we selected all working adults. Specifically, we selected all working women and all men in the smaller job categories, including seasonal workers, domestic servants, and apprentice/ trainee/interns. Within the larger strata (male government employees, male private wage workers, and self-employed men with and without non-family employees), we randomly selected $40 \%$ of the working adults. Among the target sample, we successfully completed 1966 interviews (a 98.3\% completion rate). Two individuals identified as working in the screener reported to be not working at the moment of the full interview, and we exclude them from most tables in this analysis. We created sampling weights to account for our sampling procedure and use these weights in all of our analyses. ${ }^{5}$

\subsection{Survey modules}

The survey instrument contains three main modules (plus basic information on education and training, and household characteristics). First, respondents were asked to provide information about their current job, as well as about their previous two jobs (if any) held over the past 15 years. All workers were asked basic information about employment type (see Table 1), place of work, industry, occupation, the date the job started, how the person found the job, number of employees, usual hours worked, and earnings.

The survey then asked more detailed questions about current and previous jobs, depending on whether the job was as a wage worker (government employee, private employee, day laborer/casual worker, seasonal worker, domestic worker, apprentice, intern, or trainee) or working in a household business (self-employed with or without employees, or family member working in a household business). For wage workers, the survey elicited information about employee benefits, including contract (written or verbal), sick leave, casual leave (i.e., vacation), weekly holidays, maternity leave (for women), overtime and bonus pay, pensions, and termination notice.

Table 1 Employment types

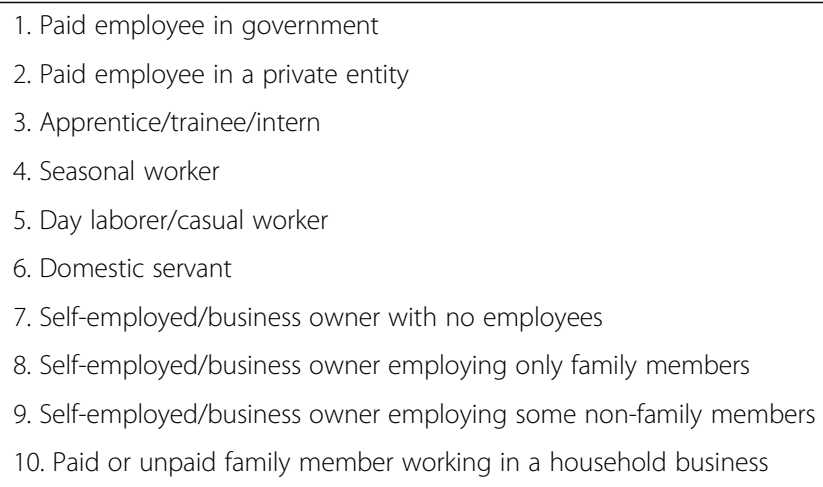


For workers in household businesses, the survey elicited information about the business itself, including registration status, number of employees, and difficulties faced in running the business. In addition, those working in household businesses were asked why they started (or worked in) those businesses. The aim of this question was to elicit subjective responses regarding whether employment in a household business was voluntary or involuntary.

The survey also contained a module on working conditions for the current job. The working condition questions included perceptions about hazards, physical violence, hygiene, and whether the worker perceived that their employer complied with agreed-upon benefits and wages. We also included questions about perceived training and promotion opportunities and about overall satisfaction.

The final main module of the survey was a choice experiment that aimed to elicit workers' preferences for specific types of benefits. The choice results are discussed in Mahmud et al. (2017). An English translation of the survey instrument (including questions about the current job and the previous jobs) is available upon request from the authors.

\subsection{Summary statistics}

Table 2 shows some basic characteristics of the sample (unweighted and weighted). The largest difference between the unweighted and weighted composition of the sample is in the percentage of women. It highlights that in Bangladesh there is a large discrepancy in the labor force participation rate by gender. According to data from the World Bank, the labor force participation for women in Bangladesh was 33\% in 2016, compared with $80 \%$ for men. ${ }^{6}$

In the weighted data, about $18 \%$ of the respondents are female. The average age of respondents is 36 years, and our sample is relatively well balanced including young workers, prime-aged workers, and older workers. Nearly $40 \%$ of workers report primary education or less; another $19.6 \%$ report some secondary education. About $25 \%$ report completing high school (HSC or diploma) or higher levels of education.

Table 2 also shows the distribution of workers by current employment type. The most common employment types are workers in private enterprises (40\%) and the self-employed (38\%, most of whom run businesses with no employees or only family employees). For the rest of the paper, we group day laborers, seasonal workers, domestic workers, and apprentices, interns, or trainees in the category "casual workers." This group represents about $12 \%$ of the sample, with day laborers and seasonal workers making up the lion's share. About $6.4 \%$ of workers are employed in government or semi-government entities.

As shown in Table 2, around $20 \%$ of workers in our sample were employed in the garments industry, with another $16 \%$ employed in other manufacturing industries. This share is higher than in Bangladesh as a whole, where only $12 \%$ of workers were employed in manufacturing in 2010 (Bangladesh Bureau of Statistics 2011). The relatively high share of employment in manufacturing in the sample is likely due to the geographic focus on urban and peri-urban areas of Dhaka and Chittagong.

Table 3 shows that among self-employed individuals and family members working in household businesses, the majority report having chosen that activity voluntarily. Only 
Table 2 Descriptive statistics

\begin{tabular}{|c|c|c|}
\hline Variable & Unweighted & Weighted \\
\hline Female & $35.3 \%$ & $18.0 \%$ \\
\hline \multicolumn{3}{|l|}{ Age } \\
\hline $18-25$ & $25.0 \%$ & $21.9 \%$ \\
\hline $26-35$ & $35.5 \%$ & $35.6 \%$ \\
\hline $36-45$ & $21.8 \%$ & $22.8 \%$ \\
\hline $46-55$ & $11.6 \%$ & $12.8 \%$ \\
\hline $56+$ & $6.1 \%$ & $6.9 \%$ \\
\hline \multicolumn{3}{|l|}{ Education } \\
\hline Pre-school or less & $18.2 \%$ & $16.5 \%$ \\
\hline Some primary (Class 1-5) & $23.4 \%$ & $22.8 \%$ \\
\hline Some secondary (Class 6-9) & $19.0 \%$ & $19.6 \%$ \\
\hline Class 10 or SSC & $14.6 \%$ & $16.0 \%$ \\
\hline HSC or diploma & $9.0 \%$ & $9.5 \%$ \\
\hline Bachelor's degree or higher & $15.5 \%$ & $15.4 \%$ \\
\hline Missing & $0.3 \%$ & $0.3 \%$ \\
\hline \multicolumn{3}{|l|}{ Vocational training } \\
\hline No vocational training & $88.4 \%$ & $88.3 \%$ \\
\hline Vocational training without certification & $3.1 \%$ & $3.2 \%$ \\
\hline Vocational training with certification & $7.8 \%$ & $7.7 \%$ \\
\hline \multicolumn{3}{|l|}{ Employment type } \\
\hline Government employees & $6.7 \%$ & $6.4 \%$ \\
\hline Private employees & $42.2 \%$ & $40.4 \%$ \\
\hline Casual workers & $12.9 \%$ & $11.7 \%$ \\
\hline Self-employed alone/with family & $24.6 \%$ & $25.7 \%$ \\
\hline Self-employed (with non-family) & $10.3 \%$ & $12.7 \%$ \\
\hline Family worker & $3.3 \%$ & $3.1 \%$ \\
\hline \multicolumn{3}{|l|}{ Industry } \\
\hline Garments & $25.4 \%$ & $20.4 \%$ \\
\hline Other manufacturing & $13.5 \%$ & $15.5 \%$ \\
\hline Trade/transportation & $22.9 \%$ & $27.8 \%$ \\
\hline Other services & $38.2 \%$ & $36.1 \%$ \\
\hline Total \# observations & 1964 & \\
\hline
\end{tabular}

Note: Summary statistics from sample of 1964 working adults who completed the survey. Employment type and industry are based on current employment type at the time of the survey

about $18 \%$ reported being self-employed because they were unable to find other work. A large fraction of respondents reported they chose to be self-employed because of the independence the work provides and because they wanted to be their own boss (46\%). Being able to earn a higher income was also an important reported reason for choosing self-employment (12\%).

Table 4 shows the distribution of benefits by current employment type, for wage workers (private employees, government employees, and casual workers). It also shows whether the averages differ in a statistically significant manner with respect to private employees (the base category). 
Table 3 Reasons for self-employment

\begin{tabular}{ll}
\hline Reason & $\%$ \\
\hline Because I was unable to find other work & 17.9 \\
Because I wanted independence / be my own boss & 45.9 \\
Because I wanted to have flexible working hours & 4.5 \\
Because I wanted higher income & 12.2 \\
Because I wanted to be close to home & 3.2 \\
Because parents, relatives or friends have their own business & 6.4 \\
Because I wanted to grow professionally & 1.8 \\
Because I wanted to have job security & 0.3 \\
Because family members wanted me to work in the business & 3.7 \\
Other & 4.3 \\
Total & 100.0
\end{tabular}

Note: Reported reasons for self-employment among self-employed individuals

Sampling weights are applied

As we would expect, benefits are most prevalent among government employees. Written contracts, sick leave, casual leave (that is, paid vacation), maternity leave (for women), and access to a Provident Fund are nearly ubiquitous among government workers. About $74 \%$ report that they would receive a termination notice if they were let go from their jobs.

Private sector employees are more likely to receive benefits than casual workers, with $25 \%$ reporting written contracts, and another $48 \%$ reporting verbal contracts. Sick leave, casual leave, and maternity leave are also fairly common. A termination notice is less common, only being reported by $45 \%$ of workers, and only around $13 \%$ report having access to a Provident Fund.

Almost no casual workers report written contracts, but over half report verbal contracts, and over $60 \%$ report sick leave. Casual leave is only reported by about $26 \%$ of casual workers; similarly, only about $27 \%$ of female casual workers report that they

Table 4 Benefits by type of employment

\begin{tabular}{llll}
\hline & Private employees (base category) & Government employees & Casual workers \\
\hline Written contract & $25.1 \%$ & $91.9 \%^{* * *}$ & $1.6 \%^{* * *}$ \\
Verbal contract & $48.2 \%$ & $5.0 \%^{* * *}$ & $51.3 \%$ \\
Sick leave & $87.7 \%$ & $98.5 \%^{* * *}$ & $63.7 \%^{* * *}$ \\
Casual leave & $61.3 \%$ & $96.6 \%^{* * *}$ & $26 \%^{* * *}$ \\
Holiday leave & $83.0 \%$ & $87.8 \%^{* *}$ & $17 \%^{* * *}$ \\
Maternity leave & $85.1 \%$ & $93.8 \%^{*}$ & $27 \%^{* * *}$ \\
Paid overtime & $33.6 \%$ & $19.4 \%^{* * *}$ & $7.3 \%^{* * *}$ \\
Bonus & $86.0 \%$ & $95.8 \%^{* * *}$ & $26.1 \%^{* * *}$ \\
Provident Fund & $12.7 \%$ & $92.9 \%^{* * *}$ & $0.6 \%^{* * *}$ \\
Gratuity & $6.4 \%$ & $71.9 \%^{* * *}$ & $0.6 \%^{* * *}$ \\
Pension & $0.7 \%$ & $82.1 \%^{* * *}$ & $0.8 \%^{*}$ \\
Termination notice & $45.3 \%$ & $73.5 \%^{* * *}$ & $14.4 \%^{* * *}$ \\
\hline
\end{tabular}

Note: Reported benefits by employment type, based on current employment type at the time of the survey. Casual worker category includes day laborers, seasonal workers, domestic workers, and apprentices, interns or trainees. Sampling weights are applied. We run $t$-tests of the difference between the prevalence of benefits among government employees and casual workers and the prevalence of benefits for private employees (the base category). ${ }^{* *}$, $*^{*}$, and $*$ denote that the $p$ value of the $t$-test is less than $0.01,0.05$, and 0.1 , respectively 
would have access to maternity leave if needed. Somewhat surprisingly, around $14 \%$ of casual workers report that they would receive a termination notice if they were let go from their jobs; nearly all of the casual workers who report this benefit are domestic workers.

Table 5 shows the 25th, 50th, and 75th percentiles of monthly income reported by individuals. We break out wage workers into the three categories discussed above, and non-wage into three additional categories: self-employed workers who either do not have any employees or only have family employees, self-employed workers who have at least one non-family employee, and family members working in household businesses. Table 5 also shows whether the reported earnings percentiles differ in a statistically significant manner with respect to private employees (the base category).

As we would expect, the median monthly income is highest for government workers, at about 25,000 Taka. Interestingly, self-employed workers report the next highest median monthly income (i.e., net profits), with those who have non-family employees reporting about 20,000 Taka, and those who do not reporting about 15,000 Taka. Private employees report a median monthly income of 9500 Taka, while casual and family workers report only 7500 Taka. We also show estimated hourly earnings, which are calculated by dividing monthly earnings by estimated number of hours worked in a month. The ranking of income estimates remains largely stable, although family workers have a higher median hourly income than casual workers.

Finally, Table 6 shows that poor working conditions are common, especially for casual workers. Nearly $80 \%$ of casual workers agree or strongly agree with the statement that they are exposed to hazards at work. While rates are lower among other types of employees, around $50 \%$ of private employees, the self-employed, and family workers, and $36 \%$ of government employees, also report being exposed to hazards.

Table 5 Earnings by employment type

\begin{tabular}{llll}
\hline Employment type & $25 \%$ percentile & $50 \%$ percentile & $75 \%$ percentile \\
\hline (a) Monthly earnings (2016 Taka) & & & 15,000 \\
Private employee (base category) & 7000 & 9500 & $35,000^{* * *}$ \\
Government employee & $15,000^{* * *}$ & $25,000^{* * *}$ & $12,000^{* * *}$ \\
Casual worker & 6000 & $7500^{* * *}$ & $20,000^{* * *}$ \\
Self-employed (alone/with family) & 7500 & $15,000^{* * *}$ & $35,000^{* * *}$ \\
Self-employed (with non-family) & $15,000^{* * *}$ & $20,000^{* * *}$ & 15,000 \\
Family worker & $2500^{* * *}$ & $7500^{* * *}$ & \\
(b) Hourly earnings (2016 Taka) & & & 267 \\
Private employee (base category) & 114 & 166 & $827^{* * *}$ \\
Government employee & $299^{* * *}$ & $476^{* * *}$ & $222^{* *}$ \\
Casual worker & 111 & $143^{* * *}$ & $370^{* * *}$ \\
Self-employed (alone/with family) & 119 & $222^{* * *}$ & $519^{* * *}$ \\
Self-employed (with non-family) & $222^{* * *}$ & $370^{* * *}$ & 286 \\
Family worker & 91 & 178 & \\
\hline
\end{tabular}

Note: Monthly earnings (panel (a)) and hourly earnings (panel (b)), by employment type. Hourly earnings are calculated based on reported monthly earnings and working hours. Earnings information is based on current job at time of survey. Casual worker category includes day laborers, seasonal workers, domestic workers, and apprentices, interns or trainees. Sampling weights are applied. We use quantile regression to test the differences between the earnings quantiles among government employees, casual workers, the self-employed, and the earnings quantiles for private employees (base category). ${ }^{* *},{ }^{* *}$, and ${ }^{*}$ denote that the associated $p$ value is less than $0.01,0.05$, and 0.1 respectively 


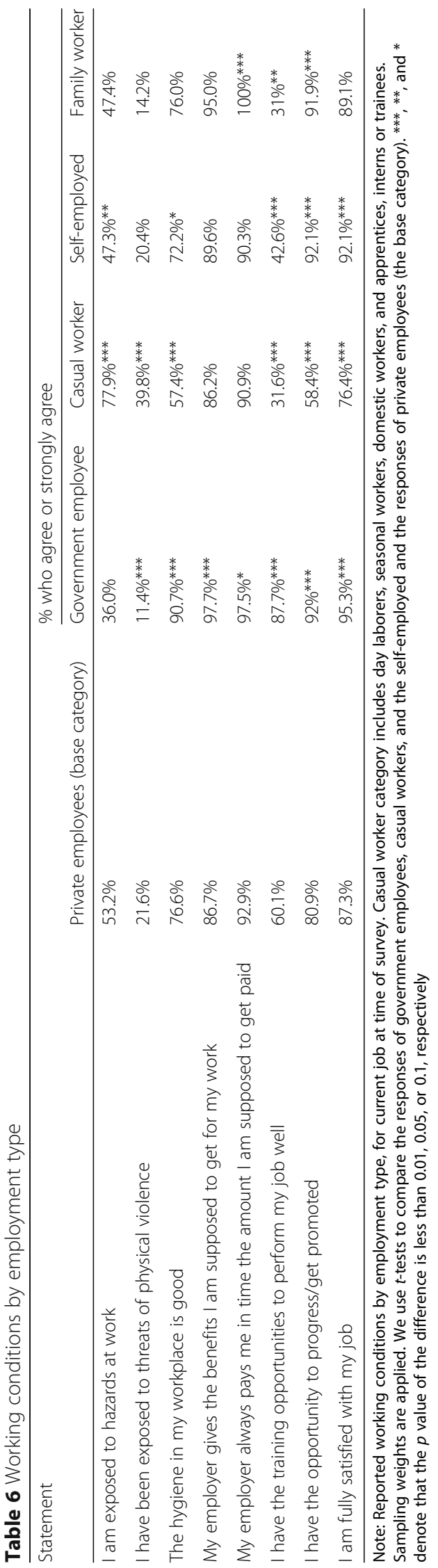


Casual workers are also more exposed to violence in the workplace. Around $40 \%$ of casual workers agree or strongly agree with the statement that they have personally been exposed to threats of physical violence, bullying, harassment, unwanted attention, or discrimination, compared with $22 \%$ of private employees, $20 \%$ of the self-employed, $14 \%$ of family workers, and $11 \%$ of government employees. Casual employees are also less likely than other types of employees to report good hygiene in the workplace.

Most workers report that they receive the benefits and pay they are supposed to get for their work. However, there is substantial variation in the share of workers who report access to opportunities for training and progression. In the case of training, casual workers, the self-employed, and family workers are all much less likely than private employees to report receiving the opportunities they need to perform their jobs well, while government employees are much more likely to report such opportunities. In the case of progression/promotion opportunities, $80-90 \%$ of all types of workers, except casual workers, report that they agree or strongly agree that they have access to such opportunities.

Finally, we note that the share of workers who agree or strongly agree with the statement that they are fully satisfied with their jobs, is generally in the range of 87-95\%, with the exception of casual workers. Even among these workers, though, around 76\% report being fully satisfied.

\section{Employment transitions}

\subsection{The frequency of, and reasons for, employment transitions}

Table 7 shows the median duration of current employment as of the survey (that is, the number of years respondents have been in their current jobs). Employees in private wage jobs have a median duration of about 4 years. Government employees have a substantially higher median duration of nearly 15 years. For casual workers, the duration is 6 years; given the way the question was asked, duration for casual workers should be interpreted as the length of time that the worker has been doing a certain type of work, although not necessarily for the same employer. ${ }^{7}$ The self-employed have a median duration of $8-10$ years in their current jobs, and family workers have a slightly shorter duration (6 years). At least part of the differences in the median duration of the current job can be explained by differences in the age distribution across employment types. Our analysis indicates that the government employees are older (median age of 41

Table 7 Median employment duration in current job (years)

\begin{tabular}{lc}
\hline & $\begin{array}{c}\text { Median } \\
\text { duration }\end{array}$ \\
\hline Government employee & 14.8 \\
Private employee & 4.3 \\
Casual worker & 6.3 \\
Self-employed worker (with no employees or with family employees) & 8.3 \\
Self-employed worker (with non-family employees) & 10.1 \\
Family worker & 6.3 \\
\hline
\end{tabular}

Note: Authors' calculations of median employment duration by employment type, based on the current job. Casual worker category includes day laborers, seasonal workers, domestic workers, and apprentices, interns or trainees. Sampling weights are applied 
years), followed by the self-employed (median age of 39 or 40, depending on whether they have non-family employees), casual workers (median age of 35 years), private employees (median age of 31 years), and family workers (median age of 30 years). To account for these imbalances in the age distribution, we use survival analysis below.

A second limitation of comparing median durations in the current job, as shown in Table 7, is that these are right-censored since we cannot know how long individuals will remain in their current jobs. To look into these issues, we first examined the total number of jobs individuals reported holding over the past 15 years (i.e., since the year 2000). ${ }^{8}$ Panel (a) of Fig. 2 shows that more than half of the workers (53\%) have held only one job (i.e., their current job) since 2000. Around 34\% of workers report two jobs over the past 15 years, and another $13 \%$ report three or more jobs during that time. Thus, workers appear to show high levels of job stability. Second, in panel (b) of Fig. 2, we estimate non-parametric survival curves (Kaplan and Meier 1958) that account for right censoring, by using information on current as well as past jobs. Consistent with

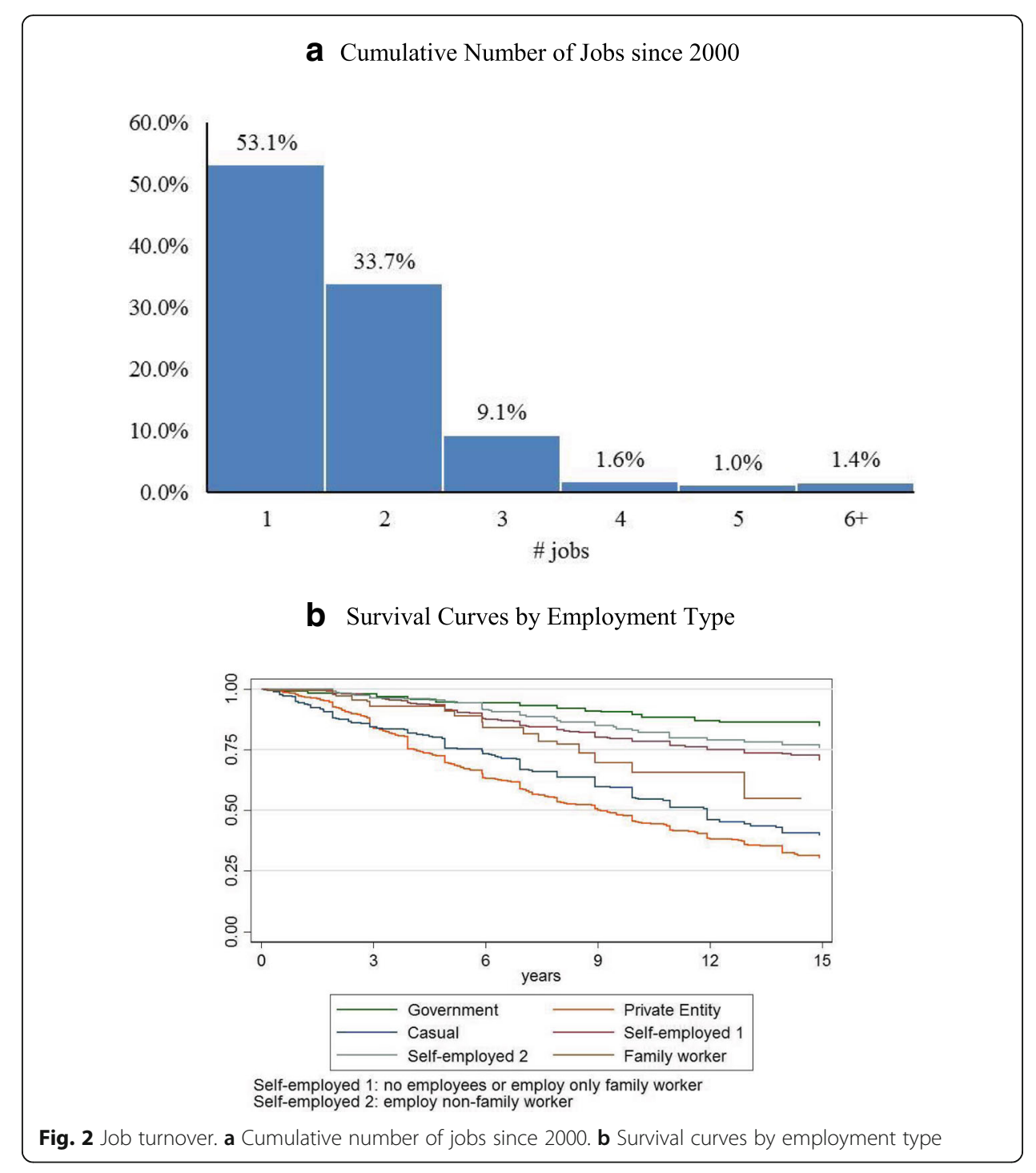


Table 8 Cox proportional hazards models

\begin{tabular}{|c|c|c|}
\hline & \multicolumn{2}{|l|}{ Hazard ratio } \\
\hline & $\begin{array}{l}\text { Not controlling for benefits } \\
\text { (1) }\end{array}$ & $\begin{array}{l}\text { Controlling for benefits } \\
\text { (2) }\end{array}$ \\
\hline Education: Class 6-9 & $1.017(0.092)$ & $1.009(0.093)$ \\
\hline Education: Class 10 and SSC & $0.979(0.109)$ & $1.053(0.117)$ \\
\hline Education: High school certificate or diploma & $1.204(0.168)$ & $1.424^{* * *}(0.195)$ \\
\hline Education: Bachelors or higher & $1.222(0.154)$ & $1.546^{* * *}(0.199)$ \\
\hline Vocational training w/o certification & $1.381 *(0.263)$ & $1.335(0.266)$ \\
\hline Vocational training $\mathrm{w} /$ certification & $1.118(0.152)$ & $1.320 * *(0.171)$ \\
\hline Male & $1.350^{* * *}(0.116)$ & $1.333^{* * *}(0.116)$ \\
\hline Age at the start of the job & $1.001(0.004)$ & $1.001(0.004)$ \\
\hline Log(monthly wage) & $0.935^{* * *}(0.023)$ & $0.959(0.025)$ \\
\hline Written contract & & $0.945(0.123)$ \\
\hline Verbal contract & & $0.975(0.086)$ \\
\hline Termination notice & & $0.631^{* * *}(0.064)$ \\
\hline Retirement benefits & & $0.385^{* * *}(0.075)$ \\
\hline Government employee & $0.135^{* * *}(0.033)$ & $0.280^{* * *}(0.082)$ \\
\hline Casual worker & $0.853(0.091)$ & $0.756^{* * *}(0.082)$ \\
\hline Self-employed (alone/with family) & $0.312^{* * *}(0.038)$ & $0.261^{* * *}(0.035)$ \\
\hline Self-employed (with non-family) & $0.242^{* * *}(0.039)$ & $0.185^{* * *}(0.032)$ \\
\hline Family worker & $0.458^{* * *}(0.104)$ & $0.391^{* * *}(0.089)$ \\
\hline Observations & 2867 & 2867 \\
\hline
\end{tabular}

Note: The duration model was estimated using a Cox proportional hazard model. Casual worker includes day laborers, seasonal workers, domestic workers, and apprentices, interns or trainees. The retirement benefits variable is coded as one if the employer offers a provident fund, gratuity or pension plan, and is coded as zero if the employer does not offer any of them. The omitted categories are primary education or less (class 5 or less), female, no vocational training, no contract, no termination notice, no retirement benefits and private employees. Other controls included in the regression analysis are industry and size of the employer. Sampling weights are applied. Standard errors in parentheses. ${ }^{* * *}$. ${ }^{* *}$ and * denote that the $p$ value is less than $0.01,0.05$, and 0.1 respectively

the results in Table 7, government jobs show the longest duration. After 5 years of employment, only $5 \%$ of workers have left a government job. This proportion increases to only $12 \%$ and $15 \%$ after 10 and 15 years of employment, respectively.

Interestingly, we find that self-employed individuals have the lowest turnover, after government employees. Only $9 \%$ of self-employed individuals who do not employ workers (or who only employ family workers) have ended their activities after 5 years. This figure increases to $21 \%$ and to $29 \%$ after 10 and 15 years, respectively. The turnover is even lower for self-employed individuals who employ non-family workers. After 5 years, only $6 \%$ have left their activities; after 10 years and 15 years, only $18 \%$ and $24 \%$, respectively, have done so. These findings are consistent with those reported above that a significant percentage of workers who choose self-employment do so voluntarily; they also stay self-employed for a long period of time.

At the other end of the spectrum, 30\% of private employees have left their jobs after 5 years of employment. This figure increases to $55 \%$ and $70 \%$ after 10 and 15 years of employment, respectively. After private employees, the next highest levels of turnover are among casual workers and family workers. After 15 years of employment, $60 \%$ of casual workers have left their type of employment, and $45 \%$ of family workers have left their jobs. 
In Table 8, we use survival analysis to investigate whether employment duration is associated with certain worker or job characteristics. This approach allows us to control for imbalances in the distribution of certain characteristics (such as age) across employment categories and also to account for right censoring in the current job, as we use information on employment duration in current as well as past jobs. The table shows the estimated effects of several variables, including employment type, in the hazard ratios using a Cox proportional hazard model specification. In this table, a statistically significant coefficient above one indicates that the variable is associated with a higher probability of leaving a job, whereas a statistically significant coefficient below one indicates that the variable is associated with a lower probability of leaving a job. A coefficient equal to 1 indicates that the variable is not associated with the probability of the worker leaving a job.

Table 8 has two specifications, one that does not include employment benefits and one that does. We present results from both specifications because access to employment benefits is to some extent determined by employment type (Table 4). For instance, as shown above, government employees have access to most benefits. And, by definition, we code employment benefits as zero for the self-employed and family workers. Thus, it is of interest to analyze how employment type is correlated with job duration both when benefits are not controlled for (or factored out) in the analysis, and when they are.

We find that having a high school diploma (or higher degree), or having completed vocational training, is associated with a higher probability of leaving a job. This finding may reflect the fact that there is greater demand for the skills of educated workers, thus allowing them greater mobility. Men also exhibit a higher probability of leaving a job. Women may exhibit lower mobility than men because they find it more difficult to take a new job due to family, scheduling, or travel constraints.

We also find that benefits, in particular a termination notice and retirement benefits, reduce the hazard rate of leaving a job. More interestingly, the duration analysis in Table 8 confirms the insights from the empirical survival curve analysis in Fig. 2b. In other words, private employees (the base category) have the highest turnover, even after controlling for differences in age, gender, earnings, education, vocational training, and benefits. In fact, Table 8 indicates almost the same pattern as Fig. 2b, with the exception that the self-employed have a lower hazard rate of separation than government employees, but only after factoring out the effects of access to employment benefits.

Column (1) in Table 8 indicates that, before controlling for differences in access to benefits, the likelihood of leaving a job for government employee is 0.135 times the likelihood of a private employee (the base category). Workers in other employment types also have lower probabilities of leaving their jobs than private employees, but higher probabilities than government employees. Column (2) in Table 8 shows that after controlling for the fact that government employees have on average higher access to benefits (Table 4), their likelihood of leaving a job increases to 0.280 times the likelihood of a private employee.

In comparison, the estimates change in the opposite direction for the self-employed after controlling for employment benefits. For instance, in column (1) of Table 8, a self-employed worker with non-family employees has a likelihood of leaving his or her job that is 0.242 times the likelihood for a private employee. This estimate decreases to 
0.185 in column (2), after factoring out the effect of not having access to employment benefits. In fact, column (2) in Table 8 shows that the self-employed with non-family employees have the lowest likelihood of leaving their employment (although the differences with government employees and the self-employed without non-family workers are not statistically significant).

The evidence above suggests that private employees are the most likely to switch jobs, and government workers and the self-employed are the least likely. In Table 9, we explore the extent to which these observed transitions are voluntary or involuntary. The survey asked all workers why they left their previous jobs (or stopped working in their previous businesses). In panel (a), we report the results based on the most recently reported job transition, for wage workers. This table shows that the most common reason for leaving a wage job is that the worker found a preferred job. Deciding to start a business is also a common answer, accounting for $20 \%$ of job transitions among

Table 9 Main reason for leaving the previous job

\begin{tabular}{|c|c|c|c|}
\hline \multicolumn{4}{|c|}{ (a) Among government employees, private employees and casual workers } \\
\hline Main reason for separation & Government employees & Private employees & $\begin{array}{l}\text { Casual } \\
\text { workers }\end{array}$ \\
\hline Terminated & $0.0 \%$ & $5.9 \%$ & $12.3 \%$ \\
\hline Firm closed & $6.3 \%$ & $7.5 \%$ & $2.0 \%$ \\
\hline Job completed & $17.5 \%$ & $2.6 \%$ & $3.3 \%$ \\
\hline Found preferred job & $33.8 \%$ & $39.1 \%$ & $22.1 \%$ \\
\hline Decided to start my own business & $6.3 \%$ & $20.1 \%$ & $16.8 \%$ \\
\hline Decided to work for family business & $0.0 \%$ & $2.3 \%$ & $2.0 \%$ \\
\hline Retired & $12.5 \%$ & $1.2 \%$ & $0.0 \%$ \\
\hline $\begin{array}{l}\text { Still work at this job, but it is no longer } \\
\text { the main activity }\end{array}$ & $0.0 \%$ & $0.8 \%$ & $8.6 \%$ \\
\hline Other (specify) & $23.7 \%$ & $19.1 \%$ & $28.4 \%$ \\
\hline Do not know & $0.0 \%$ & $0.4 \%$ & $2.0 \%$ \\
\hline Refused & $0.0 \%$ & $0.9 \%$ & $2.5 \%$ \\
\hline Total & $100 \%$ & $100 \%$ & $100 \%$ \\
\hline \multicolumn{4}{|c|}{ (b) Among self-employed and family workers } \\
\hline Main reason for separation & $\begin{array}{l}\text { Self-employed (w/o employees or } \\
\text { w/ family employees) }\end{array}$ & $\begin{array}{l}\text { Self-employed (w/ } \\
\text { non-family employees) }\end{array}$ & $\begin{array}{l}\text { Family } \\
\text { worker }\end{array}$ \\
\hline The firm did not make enough profit & $41.0 \%$ & $56.8 \%$ & $7.9 \%$ \\
\hline Found preferred job & $11.6 \%$ & $2.2 \%$ & $7.9 \%$ \\
\hline Decided to start another business & $20.0 \%$ & $9.6 \%$ & $28.4 \%$ \\
\hline $\begin{array}{l}\text { Decided to work for another family } \\
\text { business }\end{array}$ & $1.8 \%$ & $0 \%$ & $5.7 \%$ \\
\hline Retired & $1.3 \%$ & $0 \%$ & $0 \%$ \\
\hline $\begin{array}{l}\text { Still work in this business but it is no } \\
\text { longer the main activity }\end{array}$ & $9.0 \%$ & $10.9 \%$ & $13.6 \%$ \\
\hline Other & $12.5 \%$ & $20.5 \%$ & $19.3 \%$ \\
\hline Refused & $2.8 \%$ & $0 \%$ & $17.1 \%$ \\
\hline Total & $100.0 \%$ & $100.0 \%$ & $100.0 \%$ \\
\hline
\end{tabular}

Note: Reported reason for leaving the previous job, for wage workers (panel (a)) and workers in household businesses (panel (b)). Casual worker category includes day laborers, seasonal workers, domestic workers, and apprentices, interns or trainees. Sampling weights are applied 
private employees. Only $6 \%$ of private employees and $12 \%$ of casual workers report that their job was terminated. Thus, among wage workers, it appears that a substantial fraction of turnover is voluntary. This finding is particularly salient because, as noted above, private employees have the highest level of employment turnover.

Among the self-employed, panel (b) of Table 9 shows that a large fraction-nearly $41 \%$ among those with no employees or only family employees, and $57 \%$ among those with non-family member employees-report stopping their activities due to a lack of profit. In contrast with wage workers, a much smaller share report that they found a preferred job. However, $10-30 \%$ decided to start another business.

Taken together, Tables 3 and 9 and Fig. $2 \mathrm{~b}$ suggest that many individuals who are self-employed are doing so voluntarily. They have lower turnover than private wage employees and tend to leave their businesses if they cannot make a profit. Those who transition away from a wage job are much more likely to do so voluntarily than those who transition away from running a business.

\subsection{Transitions between employment types}

Table 10 documents the transition patterns for workers who move from one job to another. Each row shows the type of employment in which the worker was previously engaged, and each column shows the type of employment to which he or she moved. For the purposes of this analysis, all self-employed workers are grouped together. Overall, we find that workers who move from one job to another are quite likely to stay in the same type of job. For example, $45 \%$ of workers who leave a government job transition to another government job. Similarly, $57 \%$ of private employees ( $40 \%$ of casual workers) who transition to another job, stay in private (casual) employment. This stability is also apparent among the self-employed, with $62 \%$ of those who move out of one business where they are self-employed, going to a different business in which they remain self-employed. The only exception to this general pattern is found among family workers, where those who transition are most likely to start their own businesses.

However, Table 10 also shows that there are substantial transitions across employment types, including movement into and out of self-employment. Over 30\% of workers who leave private employment start their own businesses or go into a family business. Conversely, $26 \%$ of self-employed workers who leave their businesses take up work as private wage workers. There is also some movement between casual and

Table 10 Transition between employment categories

\begin{tabular}{llllllll}
\hline \multicolumn{1}{c}{} & \multicolumn{2}{l}{ Current employment } \\
\cline { 3 - 8 } & & $\begin{array}{l}\text { Government } \\
\text { employee }\end{array}$ & $\begin{array}{l}\text { Private } \\
\text { employee }\end{array}$ & $\begin{array}{l}\text { Casual } \\
\text { worker }\end{array}$ & $\begin{array}{l}\text { Self-employed } \\
\text { Previous }\end{array}$ & Governmily & Total \\
employment employee & $45.0 \%$ & $36.3 \%$ & $6.3 \%$ & $12.5 \%$ & $0.0 \%$ & $100.0 \%$ \\
& Private employee & $3.5 \%$ & $57.3 \%$ & $7.2 \%$ & $30.5 \%$ & $1.5 \%$ & $100.0 \%$ \\
& Casual Worker & $0.0 \%$ & $22.1 \%$ & $39.9 \%$ & $35.1 \%$ & $3.0 \%$ & $100.0 \%$ \\
& Self-employed & $0.7 \%$ & $26.1 \%$ & $11.0 \%$ & $61.6 \%$ & $0.7 \%$ & $100.0 \%$ \\
& Family worker & $0.0 \%$ & $27.3 \%$ & $22.7 \%$ & $47.7 \%$ & $2.3 \%$ & $100.0 \%$
\end{tabular}

Note: Rows show the previous type of employment, while columns show the current type of employment. Each cell shows the probability that a worker who leaves a previous job of a certain type (given by row headings) transitions to a new job of a certain type (given by column headings). Casual worker category includes day laborers, seasonal workers, domestic workers, and apprentices, interns or trainees. Sampling weights are applied 
private wage work; $7 \%$ of private employees who transition go to casual work, while $22 \%$ of casual employees who transition go to private wage work.

In Tables 11, 12, and 13, we explore the correlates of the transitions away from private, casual, and self-employment. We limit this analysis to transitions from these three types of work because they represent the majority of employment (and the majority of transitions).

In Table 11, we present the results of multinomial logit regressions (marginal effects) that describe the factors that, conditional on leaving a private wage job, are associated with transitions into different types of jobs (government, private, casual, self-employment, and family worker). We find that more educated workers leaving private employment are more likely to start another private job and less likely to transition into casual work.

Gender is not correlated with the probability of transition to specific types of work, except (and only at the $10 \%$ significance level) that men are less likely than women to transition from private employment into being a family worker.

There are also differences in transition probabilities by income (at the $10 \%$ significant level) and by tenure. Workers with higher (monthly) income and higher tenure at their jobs are less likely to start another job as a private wage employee. In particular, those with higher tenure are more likely to move into self-employment. Interestingly, at the same time, we find that older workers are more likely to start another job in private employment, and less likely to find a job in government, as a casual worker or as a family worker.

Finally, as we would expect, workers who report that they ended their employment because they found a preferred job are more likely to transition to government or private wage employment, and less likely to move to casual work or self-employment, whereas those who report ending their employment because they preferred self-employment do, in fact, move into self-employment or become family workers.

Table 12 presents a similar set of results for transitions away from casual employment, into private, casual, or self-employment. In this case, we do not show transitions into government employment or family work due to the small number of observed transitions in these categories. ${ }^{9}$ As we would expect, workers with higher levels of education are less likely to transition to other types of casual employment and more likely to transition to private wage work or self-employment. In addition, workers who have been in their casual employment for a longer period of time, are less likely to start another type of casual employment, and more likely to move into private wage employment.

Overall, these results are consistent with the idea that casual workers-particularly those with higher education-may move up the formality ladder as they gain more experience. This is also reflected in the finding that those reporting that they left their previous jobs because they found a preferred job are more likely to take a private wage job.

In Table 13, we find that among workers ending a self-employment activity, the youngest ones (those under 25, the omitted group) are more likely to transition into private employment, in comparison to workers of ages 26 to 45 . We also find that the youngest workers are less likely to start another self-employment activity, in comparison to workers of ages 26 to 35 . 


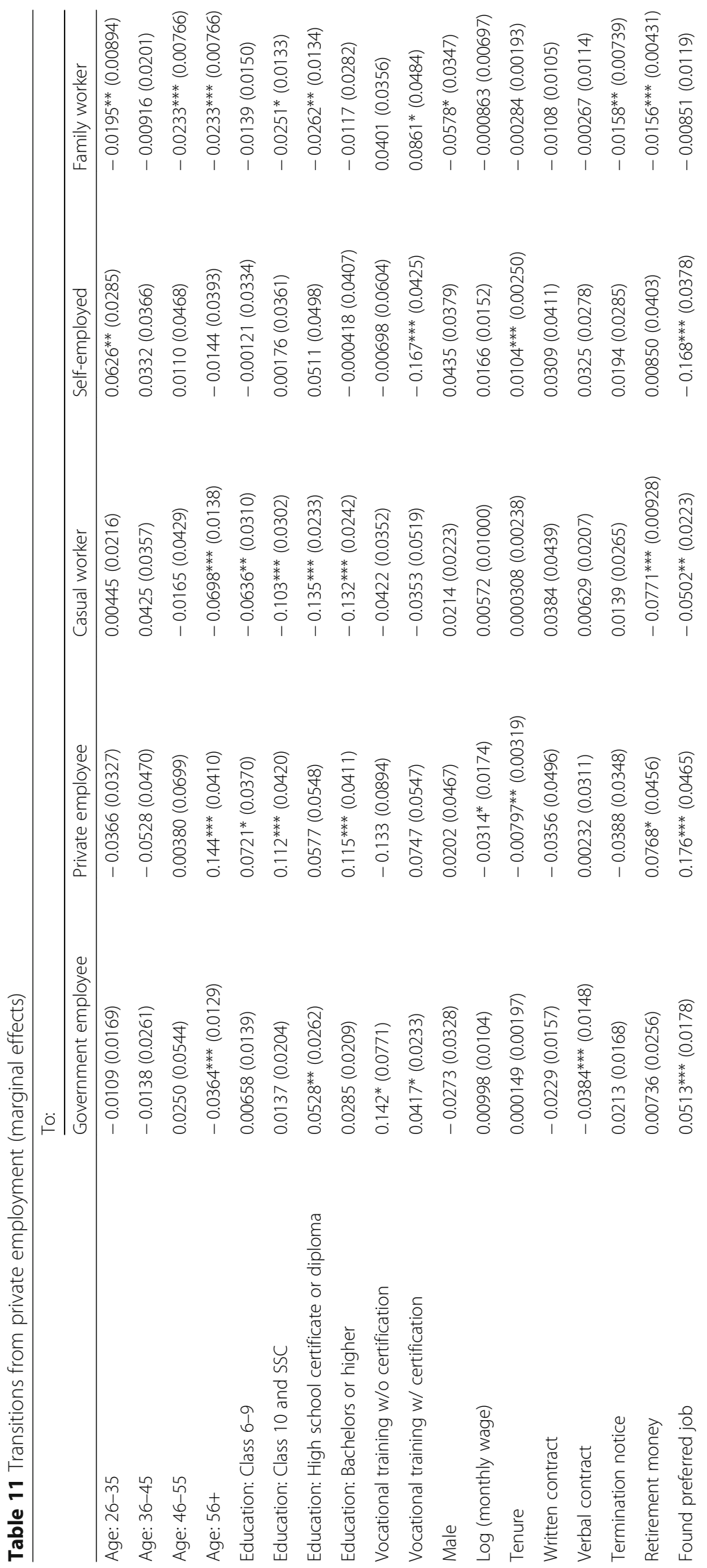




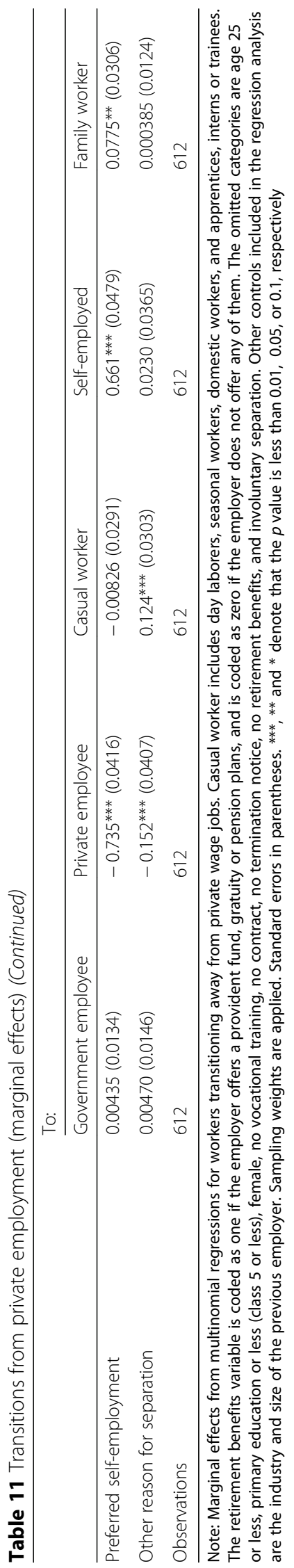


Table 12 Transitions from casual employment (marginal effects)

\begin{tabular}{llll}
\hline & To: & & \\
\cline { 2 - 4 } & Private employee & Casual worker & Self-employment \\
\hline Age: 26-35 & $-0.0474(0.0598)$ & $0.0846(0.0782)$ & $-0.0372(0.0676)$ \\
Age: 36-45 & $-0.185^{* *}(0.0761)$ & $0.0236(0.0900)$ & $0.161^{* *}(0.0674)$ \\
Age: 46-55 & $-0.148(0.115)$ & $-0.0105(0.128)$ & $0.159^{*}(0.0830)$ \\
Age: 56+ & $-0.313(0.216)$ & $0.272(0.225)$ & $0.0410(0.171)$ \\
Education: Class 6-9 & $0.121^{*}(0.0697)$ & $-0.297^{* *}(0.0994)$ & $0.175^{* *}(0.0790)$ \\
Education: Class 10 and SSC & $0.0799(0.120)$ & $-0.438^{* * *}(0.163)$ & $0.358^{* * *}(0.116)$ \\
Education: High school certificate or diploma & $-0.0313(0.483)$ & $-0.253(0.409)$ & $0.285^{*}(0.149)$ \\
Education: Bachelors or higher & - & - & - \\
Vocational training w/o certification & - & - & - \\
Vocational training w/ certification & $0.116(0.148)$ & $-0.110(0.189)$ & $-0.00555(0.144)$ \\
Male & $-0.0666(0.0951)$ & $-0.0636(0.132)$ & $0.130(0.128)$ \\
Log(monthly wage) & $-0.0196(0.0454)$ & $-0.00215(0.0552)$ & $0.0218(0.0438)$ \\
Tenure & $0.0133^{* *}(0.00520)$ & $-0.0176^{* * *}(0.00608)$ & $0.00436(0.00422)$ \\
Written contract & $-1.811(1548)$ & $1.536(1253)$ & $0.275(294.8)$ \\
Verbal contract & $-0.117^{* *}(0.0553)$ & $0.0526(0.0652)$ & $0.0641(0.0487)$ \\
Termination notice & $-0.108(0.0970)$ & $-0.204(0.134)$ & $0.311^{* * *}(0.0980)$ \\
Retirement money & - & - & - \\
Found preferred job & $0.396^{* * *}(0.0946)$ & $-0.179(0.118)$ & $-0.217^{* *}(0.104)$ \\
Preferred self-employment & $-1.721(628.7)$ & $0.940(508.9)$ & $0.781(119.7)$ \\
Other reason for separation & $0.161(0.108)$ & $-0.232^{* *}(0.108)$ & $0.0713(0.0738)$ \\
Observations & 172 & 172 & 172 \\
\hline Note: Margna & & \\
\hline
\end{tabular}

Note: Marginal effects from multinomial regressions for workers transitioning away from casual employment. Casual worker includes day laborers, seasonal workers, domestic workers, and apprentices, interns or trainees. The retirement benefits variable is coded as one if the employer offers a provident fund, gratuity or pension plans, and is coded as zero if the employer does not offer any of them. The omitted categories are age 25 or less, primary education or less (class 5 or less), female, no vocational training, no contract, no termination notice, no retirement benefits, and involuntary separation. Other controls included in the regression analysis are the industry and size of the previous employer. Sampling weights are applied. Standard errors in parentheses. ${ }^{* *},{ }^{* *}$ and ${ }^{*}$ denote that the $p$ value is less than 0.01 , 0.05 , or 0.1 , respectively

Table 13 indicates, somewhat surprisingly, that among workers ending a self-employment activity, those who have vocational training are more likely to move to casual work, and less likely to start another business. In keeping with the previous results, we also find that those who report leaving their previous self-employment activity because they found a preferred job are more likely to transition to private work.

\subsection{Employment transitions and earnings}

Next, we describe the relationship between job turnover and earnings, distinguishing by the type of employment transition. Table 14 shows that the median percentage change in monthly wages when a worker switches jobs is $2.7 \%$. However, there is wide variation in the change in monthly earnings, depending on the type of job that is ending. The median change in earnings is positive for workers ending a government job (13.6\%) or private employment $(12.0 \%)$, but zero for workers ending casual employment and negative for workers ending self-employment $(-5.2 \%$ for those with no 
Table 13 Transitions from self-employment

\begin{tabular}{llll}
\hline & & To: & \\
& Private employee & Casual worker & Self-employment \\
\hline Age: $26-35$ & $-0.298^{* * *}(0.0739)$ & $0.0484(0.0675)$ & $0.250^{* * *}(0.0887)$ \\
Age: $36-45$ & $-0.196^{* *}(0.0923)$ & $0.0619(0.0862)$ & $0.134(0.106)$ \\
Age: $46-55$ & $-0.170(0.128)$ & $0.0692(0.0998)$ & $0.101(0.144)$ \\
Age: $56+$ & $0.385(140.2)$ & $-1.441(398.9)$ & $1.056(258.7)$ \\
Education: Class 6-9 & $0.106(0.0854)$ & $-0.110(0.0813)$ & $0.00351(0.0984)$ \\
Education: Class 10 and SSC & $0.139^{*}(0.0769)$ & $-0.0890(0.0726)$ & $-0.0499(0.0927)$ \\
Education: High school certificate or diploma & $0.799(95.24)$ & $-1.639(271.0)$ & $0.840(175.8)$ \\
Education: Bachelors or higher & $0.829(63.71)$ & $-1.755(181.3)$ & $0.926(117.6)$ \\
Vocational training w/o certification & $-0.297(0.181)$ & $0.353^{* *}(0.161)$ & $-0.0562(0.216)$ \\
Vocational training w/ certification & $0.162(0.152)$ & $0.239^{* *}(0.114)$ & $-0.401^{* *}(0.185)$ \\
Male & $0.109(0.188)$ & $0.116(0.200)$ & $-0.226(0.234)$ \\
Log(monthly wage) & $-0.0425(0.0278)$ & $0.00255(0.0262)$ & $0.0400(0.0357)$ \\
Tenure & $0.0006(0.0065)$ & $-0.0010(0.0051)$ & $0.0005(0.0069)$ \\
Found preferred job & $0.377^{* * *}(0.117)$ & $0.0753(0.0910)$ & $-0.453^{* * *}(0.164)$ \\
Preferred self-employment & $0.168(59.81)$ & $-1.500(170.2)$ & $1.333(110.4)$ \\
Other reason for separation & $0.0794(0.0695)$ & $-0.0216(0.0571)$ & $-0.0578(0.0749)$ \\
Observations & 171 & 171 & 171
\end{tabular}

Note: Marginal effects from multinomial regressions for workers transitioning away from self-employment. Casual worker includes day laborers, seasonal workers, domestic workers, and apprentices, interns or trainees. The omitted categories are age 25 or less, primary education or less (class 5 or less), female, no vocational training, and involuntary separation. Other controls included in the regression analysis are the industry and size of the previous employer. Sampling weights are applied. Standard errors in parentheses. ${ }^{* *},{ }^{* *}$ and ${ }^{*}$ denote that the $p$ values is less than $0.01,0.05$, or 0.1 , respectively

employees or family employees only, and $-43.7 \%$ for those with non-family employees) or a family worker position (-25.2\%).

Table 14 also shows that there is significant variation in wage change by the next type of employment that the worker takes up. For example, workers ending a government job to take another government job experience a median increase in their earnings of $10.9 \%$, but government workers who move to a private job have a median decline of $30.8 \%$ in their monthly earnings.

Workers who end a private job have a positive median change in monthly earnings, except when they start casual employment or a self-employment activity without non-family employees. The fact that the median change in earnings for individuals leaving private employment is in most cases positive is in accordance with the finding that the majority of job separations from private employment appears to be voluntary, and associated with moving up the job ladder. It is worth noting that workers who leave private employment to start their own businesses employing non-family workers have a large median increase in monthly earnings (42.9\%).

The median change in monthly earnings for workers leaving casual employment is $0 \%$. This is explained by the fact that the majority of these workers move to another casual employment position, with a median change in income of $0 \%$. Those who move to a different type of job experience a negative median change in earnings, except those who start businesses with non-family employees (and experience a median change of $19.2 \%$ ). 
Table 14 Percentage change in earnings by employment type transition

\begin{tabular}{|c|c|c|c|c|}
\hline & \multirow{2}{*}{$\begin{array}{l}\text { Number of } \\
\text { transitions }\end{array}$} & \multicolumn{3}{|c|}{ Change in monthly earnings (\%) } \\
\hline & & 25th percentile & 50th percentile & 75th percentile \\
\hline All transitions & 828 & $-33.3 \%$ & $2.7 \%$ & $50.0 \%$ \\
\hline From government employment & 19 & $-30.8 \%$ & $13.6 \%$ & $53.0 \%$ \\
\hline To government employment & 9 & $-6.3 \%$ & $10.9 \%$ & $103.5 \%$ \\
\hline To private employment & 7 & $-33.3 \%$ & $-30.8 \%$ & $50.0 \%$ \\
\hline From private employment & 493 & $-23.5 \%$ & $12.0 \%$ & $63.7 \%$ \\
\hline To government employment & 18 & $-6.4 \%$ & $11.2 \%$ & $51.8 \%$ \\
\hline To private employment & 286 & $-11.2 \%$ & $17.1 \%$ & $57.7 \%$ \\
\hline To casual employment & 44 & $-36.3 \%$ & $-2.9 \%$ & $63.4 \%$ \\
\hline $\begin{array}{l}\text { To self-employment (no employees or } \\
\text { family employees only) }\end{array}$ & 97 & $-50.6 \%$ & $-9.6 \%$ & $68.9 \%$ \\
\hline $\begin{array}{l}\text { To self-employment (with non-family } \\
\text { employees) }\end{array}$ & 40 & $-40.9 \%$ & $42.9 \%$ & $114.3 \%$ \\
\hline To family worker & 8 & $-53.0 \%$ & $19.8 \%$ & $165.6 \%$ \\
\hline From casual employment & 140 & $-29.6 \%$ & $0.0 \%$ & $41.6 \%$ \\
\hline To private employment & 32 & $-35.4 \%$ & $-12.0 \%$ & $18.1 \%$ \\
\hline To casual employment & 59 & $-23.5 \%$ & $0.0 \%$ & $37.1 \%$ \\
\hline $\begin{array}{l}\text { To self-employment (no employees or } \\
\text { family employees only) }\end{array}$ & 34 & $-43.7 \%$ & $-6.3 \%$ & $61.5 \%$ \\
\hline $\begin{array}{l}\text { To self-employment (with non-family } \\
\text { employees) }\end{array}$ & 10 & $-6.3 \%$ & $19.2 \%$ & $53.0 \%$ \\
\hline $\begin{array}{l}\text { From self-employment (no employees or } \\
\text { family employees only) }\end{array}$ & 118 & $-35.4 \%$ & $-5.2 \%$ & $44.0 \%$ \\
\hline To private employment & 33 & $-35.4 \%$ & $-16.7 \%$ & $15.8 \%$ \\
\hline To casual employment & 17 & $-52.6 \%$ & $-26.1 \%$ & $3.4 \%$ \\
\hline $\begin{array}{l}\text { To self-employment (no employees or } \\
\text { family employees only) }\end{array}$ & 49 & $-35.4 \%$ & $2.7 \%$ & $47.7 \%$ \\
\hline $\begin{array}{l}\text { To self-employment (with non-family } \\
\text { employees) }\end{array}$ & 18 & $-6.2 \%$ & $3.6 \%$ & $44.0 \%$ \\
\hline $\begin{array}{l}\text { From self-employment (with non-family } \\
\text { employees) }\end{array}$ & 45 & $-66.7 \%$ & $-43.7 \%$ & $-17.7 \%$ \\
\hline To private employment & 10 & $-70.3 \%$ & $-44.2 \%$ & $-17.7 \%$ \\
\hline $\begin{array}{l}\text { To self-employment (no employees } \\
\text { or family employees only) }\end{array}$ & 18 & $-65.3 \%$ & $-48.3 \%$ & $-17.7 \%$ \\
\hline $\begin{array}{l}\text { To self-employment (with non-family } \\
\text { employees) }\end{array}$ & 14 & $-58.6 \%$ & $-37.9 \%$ & $-23.5 \%$ \\
\hline From family worker & 13 & $-48.3 \%$ & $-25.2 \%$ & $55.1 \%$ \\
\hline To private employment & 5 & $-74.6 \%$ & $-27.4 \%$ & $179.2 \%$ \\
\hline
\end{tabular}

Note: 25th, 50th, and 75th percentiles of changes in monthly earnings when transitioning from one employment type to another. Only cells (e.g., from private employment to casual employment) with 5 or more transitions are shown. Casual worker category includes day laborers, seasonal workers, domestic workers, and apprentices, interns or trainees. Sampling weights are applied

The median change in monthly earnings for individuals leaving self-employment activities with no employees (or with family employees only) is negative, except for those who start another self-employment activity-particularly if the new activity involves a business that hires non-family member employees. It is interesting to note that the median change in monthly earnings for those who leave self-employment with no employees (or family employees only) to start a private 
job is negative $(-16.7 \%)$. These findings are in line with the evidence presented above that ending a self-employment activity is in the majority of the cases involuntary (not making sufficient profit) rather than because the self-employed have found preferred jobs (Table $9 \underline{b}$ ).

Overall, these findings suggest that private wage employment may not always be preferable to self-employment. This is particularly true for self-employed businesses that look more like entrepreneurial startups (i.e., hire non-family members) and less like household businesses. In keeping with these findings, self-employed workers who employ non-family members, and who transition to other types of work, exhibit large drops in monthly income, regardless of what activities they transition into. We similarly see a wage drop among those who are family workers in household businesses, when they transition to private wage employment; however, it is possible that self-employed and family workers are trading off income against other benefits of wage employment, such as job stability. ${ }^{10}$

\subsection{Employment transitions and job benefits}

In this section, we draw on the rich set of information gathered in the survey on job benefits, to examine whether and how such benefits change as workers transition between jobs. Our transition data allow us to examine whether workers continually move "up" the ladder of formality, in terms of acquiring more benefits.

Table 15 shows a transition matrix, similar to that shown in Table 10, but based on benefits instead of employment type. In panel (a), the rows show the type of contract that the worker had in the previous job, while the columns show the type of contract in the current job. Self-employed and family workers are shown separately. As with the transition across employment types, we find a substantial amount of stability in benefits. About $50 \%$ of workers who leave a job with a written contract start a new job with a written contract; a similar share of workers with a verbal contract (no contract) in the previous job has the same level of benefit in the next job. However, we also find evidence of movement both up and down the formality ladder. About $11 \%$ of workers who previously had a verbal contract report a written one, and $8 \%$ of workers who previously had a written contract, now report a verbal one. Transitions across more than one level of benefit (from no contract to written contract, or vice versa) are less common but are observed. Similarly, panel (b) shows that whether a worker receives a termination notice is fairly stable, but $15 \%$ of workers who leave a job with a termination notice go to a wage job without a termination notice, while 13\% move from a job without a termination notice into a job with a termination notice.

If transitions into and out of self-employment are added, the churn between levels of benefits becomes even more pronounced. For example, in the case of a termination notice, nearly $50 \%$ of those who leave a job with a termination notice move into either a wage job without a termination notice or into self-employment.

Analyses of other benefits (sick leave, casual leave, holiday leave, maternity leave, paid overtime, bonuses and retirement benefits) yield similar findings and are not presented here. In Fig. 3, we summarize our findings on benefit transitions by showing the overall change in the number of benefits that are observed when a worker changes jobs. The red bars include only people leaving wage employment (i.e., jobs in government, private 
Table 15 Change in access to employment benefits between job transitions

(a) Contracts

\begin{tabular}{|c|c|c|c|c|c|c|c|}
\hline & & \multicolumn{6}{|c|}{ Current job } \\
\hline & & $\begin{array}{l}\text { Written } \\
\text { contract }\end{array}$ & $\begin{array}{l}\text { Verbal } \\
\text { contract }\end{array}$ & No contract & $\begin{array}{l}\text { Self-employment; } \\
\text { family worker }\end{array}$ & $\begin{array}{l}\text { Do } \\
\text { not } \\
\text { know }\end{array}$ & Total \\
\hline \multirow[t]{4}{*}{$\begin{array}{l}\text { Previous } \\
\text { Job }\end{array}$} & $\begin{array}{l}\text { Written } \\
\text { contract }\end{array}$ & $48.0 \%$ & $7.8 \%$ & $3.1 \%$ & $38.4 \%$ & $2.7 \%$ & $100.0 \%$ \\
\hline & $\begin{array}{l}\text { Verbal } \\
\text { contract }\end{array}$ & $10.7 \%$ & $49.8 \%$ & $6.1 \%$ & $32.0 \%$ & $1.5 \%$ & $100.0 \%$ \\
\hline & No contract & $6.9 \%$ & $13.4 \%$ & $52.3 \%$ & $26.3 \%$ & $3.0 \%$ & $100.0 \%$ \\
\hline & $\begin{array}{l}\text { Self-employment; } \\
\text { family worker }\end{array}$ & $7.6 \%$ & $20.6 \%$ & $8.3 \%$ & $61.6 \%$ & $1.9 \%$ & $100.0 \%$ \\
\hline
\end{tabular}

(b) Termination notice

\begin{tabular}{|c|c|c|c|c|c|c|}
\hline & & \multicolumn{5}{|l|}{ Current job } \\
\hline & & $\begin{array}{l}\text { Termination } \\
\text { notice }\end{array}$ & $\begin{array}{l}\text { No termination } \\
\text { notice }\end{array}$ & $\begin{array}{l}\text { Self-employment; } \\
\text { family worker }\end{array}$ & Do not know & Total \\
\hline \multirow[t]{3}{*}{$\begin{array}{l}\text { Previous } \\
\text { Job }\end{array}$} & $\begin{array}{l}\text { Termination } \\
\text { notice }\end{array}$ & $44.4 \%$ & $15.2 \%$ & $32.9 \%$ & $7.5 \%$ & $100.0 \%$ \\
\hline & $\begin{array}{l}\text { No termination } \\
\text { notice }\end{array}$ & $12.8 \%$ & $50.4 \%$ & $30.0 \%$ & $6.9 \%$ & $100.0 \%$ \\
\hline & $\begin{array}{l}\text { Self- } \\
\text { employment; } \\
\text { family worker }\end{array}$ & $14.5 \%$ & $19.2 \%$ & $61.6 \%$ & $4.8 \%$ & $100.0 \%$ \\
\hline
\end{tabular}

Note: Rows show the status of job benefit in the previous job, while columns show the status of job benefit in the current job. Panel (a) covers contracts and indicates whether the job included a written contract, a verbal contract, or no contract, or was non-wage work (self-employment/family worker). Panel (b) covers notice, and indicates whether the job included a termination notice or not, or was non-wage work. Each cell shows the probability that a worker who leaves a previous job with a certain benefit status (given by row headings) transitions to a new job with a certain benefit status (given by column headings). We excluded the "do not know" category for previous job benefit status. Sampling weights are applied

employment and casual employment). The blue bars show transitions for all workers, including those leaving self-employment and family work. As this figure illustrates, when a worker moves to a new job, he or she has a high probability of retaining or increasing his or her number of benefits. However, there is also a substantial risk of having access to fewer benefits. For example, considering only those who transition out of

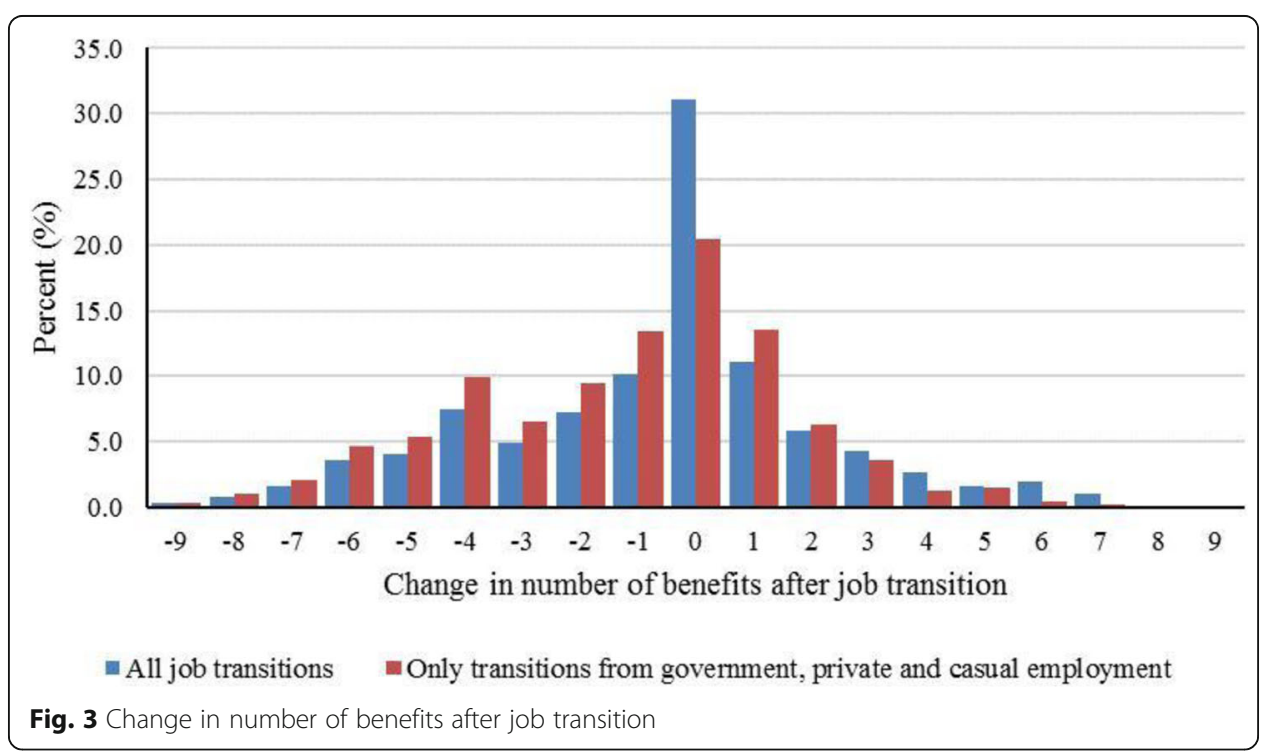


wage employment, about $47 \%$ maintain or increase the number of benefits, while $53 \%$ have access to fewer of them. When taking into account all job transitions (i.e., including those leaving self-employment and family workers), we find that $60 \%$ maintain or gain more benefits, while $40 \%$ have access to fewer. It is not surprising that adding transitions away from self-employment and family work results in a lower risk of losing access to benefits and a higher probability of gaining benefits since by definition the self-employed and family workers do not have access to these employment benefits.

Finally, we regressed the change in the number of employment benefits after transitioning jobs on worker characteristics and on the reason for leaving the previous job. Table 16 shows that older workers are somewhat more likely to move to jobs with a smaller number of employment benefits. Leaving a job with higher earnings is associated with a loss in the number of employment benefits, suggesting that higher paying jobs also offer more benefits. We also find that leaving a job with higher tenure is associated with a loss in the number of benefits, particularly when we focus only on transitions from government, private, and casual employment.

The largest determinant of the change in the number of benefits is the reason for leaving the previous job. Workers who voluntarily leave for a preferred job are more likely to report an increase in the number of employment benefits relative to those who leave involuntarily (due to termination, firm closure, or a job ending). On average, workers who leave voluntarily exhibit an increase of one benefit (two when we consider

Table 16 Correlates of changes in the number of employment benefits after job transition

\begin{tabular}{lll}
\hline & All job transitions & $\begin{array}{l}\text { Only transitions from } \\
\text { government, private and } \\
\text { casual employment }\end{array}$ \\
\hline Age: 26-35 & $-0.321(0.195)$ & $-0.269(0.198)$ \\
Age: 36-45 & $-0.252(0.257)$ & $-0.365(0.269)$ \\
Age: 46-55 & $-0.0511(0.362)$ & $0.0532(0.376)$ \\
Age: 56+ & $-1.003^{*}(0.532)$ & $-1.039^{*}(0.585)$ \\
Education: Class 6-9 & $-0.358(0.223)$ & $-0.431^{*}(0.226)$ \\
Education: Class 10 and SSC & $0.0465(0.253)$ & $-0.298(0.275)$ \\
Education: High school certificate or diploma & $0.157(0.325)$ & $-0.301(0.337)$ \\
Education: Bachelors or higher & $0.145(0.273)$ & $-0.472(0.289)$ \\
Vocational training w/o certification & $-0.336(0.439)$ & $0.0465(0.437)$ \\
Vocational training w/ certification & $-0.123(0.312)$ & $-0.0005(0.305)$ \\
Male & $-0.132(0.274)$ & $-0.177(0.265)$ \\
Log (monthly wage) & $-0.175^{* *}(0.0881)$ & $-0.299^{* * *}(0.110)$ \\
Tenure & $-0.0185(0.0157)$ & $-0.0325^{* *}(0.0164)$ \\
Found preferred job & $1.109^{* * *}(0.225)$ & $2.021^{* * *}(0.252)$ \\
Preferred self-employment & $-3.692^{* * *}(0.260)$ & $-2.712^{* * *}(0.272)$ \\
Other reason for separation & $-0.549^{* *}(0.233)$ & $-0.171(0.262)$ \\
Observations & 788 & 638 \\
\hline Note: Resuls from a linear res &
\end{tabular}

Note: Results from a linear regression model. The dependent variable is the change in the number of benefits given an employment transition. Casual worker includes day laborers, seasonal workers, domestic workers, and apprentices, interns or trainees. The omitted categories are age 25 or less, primary education or less (class 5 or less), female, no vocational training, and involuntary separation. Other controls included in the regression analysis are the industry and size of the previous employer. Sampling weights are applied. Standard errors in parentheses. ${ }^{* *},{ }^{* *}$, and 8 denote that the $p$ value is less than $0.01,0.05$, or 0.1 , respectively 
only transitions away from wage employment). Not surprisingly, workers who report leaving their previous jobs because they preferred self-employment (or working in a family business) report losing more employment benefits than those who ended their employment involuntarily. This is because these workers are indeed more likely to transition into self-employment and thus do not retain any employment benefits (Tables 11 and 12).

\section{Conclusions}

In this paper, we present the first evidence we are aware of on how and whether workers transition between different types of employment in Bangladesh. We find that private wage workers exhibit the shortest employment durations (about 4 years), whereas government workers exhibit the longest (about 15 years). The self-employed also have much longer job durations than private wage workers, ranging from 8 years (for those who do not have employees, or who only hire family members) to 10 years (for those who hire non-family members).

Although workers who transition from one job to another are most likely to remain in the same type of employment, we do see substantial amounts of churn between employment types. Over $30 \%$ of those who leave private employment move to self-employment or work in a household business and another $7 \%$ move into casual work. Transitions from private wage employment to casual work are more common among those with lower levels of education, whereas transitions to self-employment are more common among those who have been in their jobs for longer. Our findings also show that when workers transition out of private sector employment, they tend to exhibit gains in median earnings. In addition, about half of those who leave private wage employment retain the same number of employment benefits as in their previous jobs or obtain more benefits. These findings are consistent with the fact that the most common reason provided for leaving a private wage job is that a more preferred job is found. In our analysis, voluntary quits are associated with a greater increase in the number of employment benefits. ${ }^{11}$ Thus, the higher turnover (and shorter employment duration) among private wage employees may be evidence of upward mobility, with workers leaving one job when they find a better one. Nevertheless, we also find a non-negligible risk of downward mobility, in terms of earnings and access to employment benefits, especially for those transitioning into casual employment.

Casual work appears to be the least remunerative type of employment, providing the least number of benefits, and the most likely to expose workers to hazards, violence, and poor hygiene. Nonetheless, we do see some evidence of transition out of casual work into private wage work and self-employment, particularly among those with higher levels of education.

Taken together, our results also suggest that self-employment is not always an activity of last resort in Bangladesh. While evidence of transition into and out of self-employment, by itself, does not refute the traditional view of segmented labor markets, the reported reasons for self-employment provide some support to the idea that self-employment may be valued. Even among the self-employed who do not hire non-family members, most report their self-employment as voluntary; only $18 \%$ of the self-employed report that they started a business because they were unable to find work. The reasons for leaving previous jobs also support this finding. In general, the most common reason given for leaving a wage job is because a preferred job was found, followed by the desire to start a business. In contrast, the most common reason for 
leaving a self-employed activity was that the activity failed to make a profit. Moreover, among the self-employed who hire non-family member employees, we find that moving from private wage employment into this type of self-employment is associated with an increase in income.

Overall, our findings suggest that the informal sector contains elements of both the traditional, segmented view and the dynamic, entrepreneurial view. The modal worker who changes jobs appears to remain in the same type of employment, with the same level of benefits, but there is substantial upward as well as downward mobility in terms of earnings and benefits.

\section{Endnotes}

${ }^{1}$ For example, Maloney (1999) examines employment transitions for workers in Mexico across five quarters.

${ }^{2}$ This continuous measure is particularly salient in the South Asian context, where informality encompasses a broad range of jobs, including those in small and/or unregistered enterprises, as well as in self-employment. In contrast, in Latin America, informality is often defined based on whether the worker receives social security and health benefits.

${ }^{3}$ The sample included 50 mouzas from Dhaka zila, 7 from Gazipur zila, 4 from Narayanganj zila, and 19 from Chittagong zila.

${ }^{4}$ The replacement rules for the household selection were as follows: If the enumerator was unable to talk to someone at the selected household, or if the potential respondent was busy, the enumerator would return up to two more times (up to three visits). If the household could not be reached after three visits, or refused to participate, the enumerator would choose the household next door. If this first replacement was also unsuccessful, the enumerator would select the household next door to that one. If the second replacement was also unsuccessful, the enumerator would go on to the next original household (i.e., 10th household).

${ }^{5}$ To make the sample representative of the working population in the four targeted zilas, we construct weights that take into account the stratified sample. A working adult in zila $j$ and strata $k$ had a probability of $\left(\frac{n_{j}}{N}\right)\left(\frac{30}{n_{j}}\right)\left(\right.$ Strata $\left._{k}\right)$ of being part of the sample, where $n_{j}$ is the number of households in the mouza and $N$ is the total number of households across all mouzas in the four targeted zilas. Thus, the first parenthesis $\left(\frac{n_{j}}{N}\right)$ describes the probability of a mouza being selected for the study, with sampling probability proportional to size. The second parenthesis $\left(\frac{30}{n_{j}}\right)$ denotes the random sampling of 30 households in each mouza. The third parenthesis $\left(\operatorname{Strata}_{k}\right)$ equals 1 for women and for men who are seasonal workers, domestic servants, or apprentice/trainee/interns, and equals 0.4 for all other working men. Note, however, that the sampling probability can be simplified to $\left(\frac{30}{N}\right)$ (Strat $\left.a_{k}\right)$. Since the first parenthesis is common to all individuals in the sample, we further simplified the construction of the sampling weights to the inverse of the sampling probability within the strata $\left(1 / \mathrm{Strata}_{k}\right)$. In other words, the sampling weights were either 1 or 2.5 depending on the corresponding strata.

${ }^{6}$ Statistics obtained from World Bank website (http://datatopics.worldbank.org/gender/country/bangladesh).

${ }^{7}$ For example, a worker may have been a day laborer in construction for 10 years but may have worked at many construction sites for many supervisors during that time. 
${ }^{8}$ Again, for casual workers, this should be interpreted as the number of types of jobs.

${ }^{9}$ In fact, we do not observe any casual workers who move immediately to government employment.

${ }^{10} \mathrm{We}$ explore these tradeoffs more explicitly in the choice experiments conducted as part of the survey, which are discussed in Mahmud et al. (2017).

${ }^{11}$ Although it is not shown in the paper, voluntary quits are also associated with larger gains in earnings.

\section{Acknowledgements}

We thank Sujeong Park for valuable research assistance, the editor and an anonymous referee for valuable comments. We also thank Yasuyuki Sawada and seminar participants at the Asian Development Bank Institute (Tokyo) and at the Bangladesh Institute of Development Studies (Dhaka) for helpful comments and suggestions. Responsible editor: Hartmut F. Lehmann.

\section{Funding}

This document is an output from a project funded by the UK Department for International Development (DFID) and the Institute for the Study of Labor (IZA) for the benefit of developing countries (IZA/DFID GLM|LIC Program, grant number GA-C3-RA1-299). The views expressed are not necessarily those of DFID or IZA. Dr. Kumar acknowledges additional support from the Rosenfeld Program on Asian Development at the Pardee RAND Graduate School.

\section{Availability of data and materials}

Data and copies of the computer programs used to generate the results presented in the paper are available from the lead author at italo@rand.org

\section{Competing interests}

The IZA Journal of Development and Migration is committed to the IZA Guiding Principles of Research Integrity. The authors declare that they have observed these principles.

\section{Publisher's Note}

Springer Nature remains neutral with regard to jurisdictional claims in published maps and institutional affiliations.

\section{Author details}

${ }^{1}$ RAND Corporation, 1776 Main Street, Santa Monica, CA 90407, USA. Bangladesh Institute of Development Studies, E-17 Agargaon, Dhaka 1207, Bangladesh. ${ }^{3}$ BRAC University, 66, Mohakhali, Dhaka 1212, Bangladesh.

Received: 16 August 2018 Accepted: 1 January 2019

Published online: 13 February 2019

\section{References}

Arias J, Artuc E, Lederman D, Rojas D (2013) "Trade, informal employment and labor adjustment costs." World Bank Policy Research Working Paper No. 6614

Bangladesh Bureau of Statistics. 2011. Report on Labour Force Survey 2010

Bangladesh Bureau of Statistics. 2013. Labour Force Survey 2013

Bosch M, Maloney WF (2010) Comparative analysis of labor market dynamics using Markov processes: an application to informality. Labour Econ 17(4):621-631

Chandra V, Khan MA (1993) "Foreign investment in the presence of an informal sector." Economica, pp 79-103

Djankov S, Ramalho R (2009) Employment laws in developing countries. J Comp Econ 37(1):3-13

Fajnzylber P, Maloney W, Rojas GM (2006) Microenterprise dynamics in developing countries: how similar are they to those in the industrialized world? Evidence from Mexico. World Bank Econ Rev 20(3):389-419

Fields GS (1975) Rural-urban migration, urban unemployment and underemployment, and job-search activity in LDCs. J Dev Econ 2(2):165-187

Goldberg PK, Pavcnik N (2003) The response of the informal sector to trade liberalization. J Dev Econ 72(2):463-496

Harris JR, Todaro MP (1970) Migration, unemployment and development: a two-sector analysis. Am Econ Rev 60(1):126-142

ILO. 2014. Global Employment Trends 2014: Risk of a jobless recovery? International labour office

Kaplan EL, Meier P (1958) Nonparametric estimation from incomplete observations. J Am Stat Assoc 53(282):457-481

LaPorta RL, Shleifer A (2008) The unofficial economy and economic development. Brook Pap Econ Act 2008(2):275-363

Loayza N, Oviedo AM, Serven L (2005) The impact of regulation on growth and informality cross-country evidence

Mahmud M, Gutierrez I, Kumar K, Nataraj S (2017) "What aspects of formality do Workers value? Evidence from a choice experiment in Bangladesh." GLM-LIC Working Paper No 37

Maloney WF (1999) Does informality imply segmentation in urban labor markets? Evidence from sectoral transitions in Mexico. World Bank Econ Rev 13(2):275-302

Nataraj S (2011) The impact of trade liberalization on productivity: evidence from India's formal and informal manufacturing sectors. J Int Econ 85(2):292-301

Paz LS (2014) The impacts of trade liberalization on informal labor markets: a theoretical and empirical evaluation of the Brazilian case. J Int Econ 92(2):330-348

World Bank. 2018. Data Bank. GDP growth (annual \%) and GDP per capita growth (annual \%). Downloaded from https://data. worldbank.org on December 11, 2018 